\title{
KETERBUKAAN INFORMASI PUBLIK DI PERBANKAN
}

\author{
Prima Satya Irianto1, Budi Ispriyarso². \\ Program Studi Magister Ilmu Hukum \\ Fakultas Hukum Universitas Diponegoro \\ budiispriyarso@ymail.com
}

\begin{abstract}
ABSTRAK
Semangat meningkatkan peran publik terhadap informasi guna mewujudkan tata kelola pemerintahan yang bersih. Sehingga pemerintah bersama legislator melahirkan Undang - Undang Nomor 14 Tahun 2008 Tentang Keterbukaan Informasi Publik guna melindungi hak warga Negara atas akses informasi yang dijamin oleh konstitusi. Namun disisi lain perbankan yang menjadi penggerak sektor ekonomi mengalami kesulitan dalam mengimplementasikan Undang - Undang Nomor 14 Tahun 2008 Tentang Keterbukaan Informasi Publik. Poblem penelitian tentang penerapan peraturan perundang undangan keterbukaan informasi di perbankan dan penerapan manajemen risiko dalam penerapan keterbukaan informasi publik di perbankan serta ketiga keterbukaan informasi publik yang ideal di perbankan. Metode penelitian menggunakan pendekatan yuridis empiris. Berdasarkan hasil penelitian diketahui bahwa perbankan telah menjalankan praktek keterbukaan informasi kepada publik secara parsial sebelum diterbitkan Undang - Undang Nomor 14 Tahun 2008 Tentang Keterbukaan Informasi Publik. Produk hukum keterbukaan informasi publik ini bertentangan dengan prinsip etika dalam perbankan (khususnya keterrbatasan pemberian keterangan) dan produk hukum lainnya. Berbagai benturan kepentingan dalam keterbukaan informasi publik memerlukan upaya mitigasi risiko secara komprehensif. Upaya melaksanakan ketentuan informasi oleh perbankan dapat dijalankan dengan salah satu cara penerapan informasi publik berbasiskan manajemen risiko dan pembentukan peraturan pelaksanaan keterbukaan informasi publik di perbankan yang diterbitkan oleh regulator menjadi sebuah kebutuhan. Diperlukan sebuah pembentukkan peraturan pelaksanaan keterbukaan informasi publik di perbankan guna menghindari risiko dalam pelaksanaanya sekaligus perlu dilakukan kaji ulang Undang - Undang Nomor 14 Tahun 2008 Tentang Keterbukaan Informasi Publik.
\end{abstract}

\section{Kata Kunci : Manajemen Risiko; Informasi Publik; Perbankan}

\footnotetext{
1 Mahasiswa Program Studi Magister IImu Hukum UNDIP

2 Penulis Kedua, Penulis Koresponden
} 


\section{A. PENDAHULUAN}

\section{A.1. Latar Belakang}

Keterbukaan akses informasi sebagai perwujudan interkoneksi antar manusia yang semakin intensif akibat globalisasi tidak dapat dielakkan. Hal ini memberikan perspektif baru terhadap pola hubungan antara warga negara dan negara. Aksesibilitas terhadap informasi sebagai bagian dari keterbukaan informasi publik menjadi sebuah syarat dalam mewujudkan Tata Kelola Pemerintahan Yang Baik (Good Corporate Governance). Pemerintah Republik Indonesia telah menjamin hak konstitusional warga negara untuk mengakses informasi publik baik secara hierakis yang dimulai dari Undang - Undang Dasar RI Tahun 1945 Negara Republik Indonesia, Undang Undang Nomor 14 Tahun 2008 Tentang Keterbukaan Informasi Publik sampai dengan peraturan pelaksanaannya.. Hal ini ditunjukan dengan penyampaian informasi kepada masyarakat dan/ atau nasabah baik menggunakan media cetak maupun elektronik. Namun dilaksanakan berdasarkan instrumen peraturan terkait kegiatan operasional bank yang dikeluarkan oleh regulator. Pelaksanaan keterbukaan informasi perbankan harus dijalankan secara seksama mengingat industri perbankan diwajibkan menjalankan penerapan manajemen risiko (risk management) dalam kegiatan usahanya. Didalamnya terdapat kewajiban bagi perbankan untuk mengelola informasi agar tidak mengganggu kegiatan usaha bank karena terkait pengelolaan risiko.

Persoalan tumpang tindihnya Undang Undang Nomor 14 Tahun 2008 Tentang Keterbukaan Informasi Publik dengan Undang Undang Nomor 10 Tahun 1998 Tentang Perbankan menimbulkan persoalan yang berpotensi mengganggu kegiatan operasional bank. Secara Das Sollen, produk hukum terkait keterbukaan informasi publik di perbankan dapat menjamin keberlangsungan usaha perbankan dan aksesibilitas informasi publik sebagaimana diamanatkan dalam konstitusi. Namun secara Das Sein masih terdapat sejumlah permasalahan antara lain: batasan informasi yang dapat diakses publik, mekanisme permintaan informasi publik di perbankan, mekanisme pengukuran informasi berbasis manajemen risiko, penyusunan matriks informasi yang dapat/ tidak dapat diakses publik, dan sebagainya.

Berdasarkan uraian tersebut diatas, penulis tertarik untuk melakukan penelitian dengan judul "Keterbukaan Informasi Publik Di Perbankan".

\section{A.2. Perumusan Masalah}

Berdasarkan uraian pada latar belakang penelitian, maka dapat dirumuskan sebagai berikut: 
a. Bagaimanakah penerapan peraturan perundang - undangan keterbukaan informasi di perbankan?

b. Bagaimanakah penerapan manajemen risiko dalam penerapan keterbukaan informasi publik di perbankan?

c. Bagaimanakah keterbukaan informasi publik yang ideal di perbankan?

\section{A.3. Tujuan Penelitian}

Secara umum penelitian ini dimaksudkan untuk mendeskripsikan secara analitis tentang peraturan perundang - undangan yang mengatur keterbukaan informasi di perbankan, sedangkan secara khusus tujuan penelitian ini adalah sebagai berikut:

a. Untuk memberikan pelaksanaan peraturan perundang - undangan keterbukaan informasi publik di perbankan (baik kondisi, implementasi serta metode yang digunakan).

b. Untuk mengetahui dan mengkaji prinsip penerapan manajemen risiko dalam penerapan keterbukaan informasi di perbankan.

c. Untuk mengetahui keterbukaan informasi publik yang ideal di perbankan.

\section{B. Metode Penelitian}

\section{B.1. Metode Pendekatan}

Penelitian ini akan mengkaji berbagi pokok permasalahan melalui pendekatan yuridis - empiris. Pendekatan yuridis - empiris adalah melakukan analisis terhadap permasalahan dan penelitian melalui pendekatan terhadap asas asas hukum yang mengacu pada norma - norma atau kaidah - kaidah hukum positif yang berlaku. Penelitian hukum pada hakikatnya merupakan suatu kegiatan ilmiah yang didasarkan pada metode, sistematika dan pemikiran tertentu yang bertujuan untuk mempelajari satu atau beberapa gejala hukum tertentu dengan jalan menganalisisnya ${ }^{3}$. Salah satu pendekatan dalam penelitian normatif adalah pendekatan Perundang Undangan (Statute Approach), karena yang akan diteliti adalah berbagai aturan hukum yang menjadi fokus sekaligus pusat dari suatu penelitian ${ }^{4}$. Selain itu, penelitian ini juga menggunakan pendekatan yuridis - komparatif antara Undang - Undang Nomor 14 Tahun 2008 tentang Keterbukaan Informasi Publik dan peraturan perundang undangan di perbankan yang terkait keterbukaan informasi publik berdasarkan ruang lingkup dan identifikasi masalah yang ditemukan dalam penelitian ini. Hal ini dimaksudkan agar penelitian ini untuk dapat mengetahui dan menggali data secara komprehensif yang terkait peraturan

3 Burhan Bungin, Analisis Data Penelitian Kualitatif, Pemahaman Filosofis dan Metodologis Ke Arah Penguasaan Model Aplikasi, (Jakarta: Raja Grafindo Persada, 2003), halaman 83.

4 Johny Ibrahim, Teori dan Metodologi Penelitian Hukum Normatif, (Malang: Bayu Media, 2006) halaman 302. 
perundang - undangan keterbukaan informasi di perbankan dalam perspektif tentangnya dari berbagai sudut pandang atau bersifat multi perspektif.

\section{B.2. Spesifikasi Penelitian}

Guna menggali pokok permasalahan dalam penulisan jurnal ini dipergunakan spesifikasi penelitian deskriptif analitis, yaitu penelitian yang dimaksudkan untuk menggambarkan tentang manusia, keadaan/ gejala - gejala/ symptoms lainnya yang terdapat dalam penelitian ini (baik yang bersifat fisik ataupun non fisik) ${ }^{5}$.

Tujuan dari penelitian deskriptif analitis adalah berusaha menggambarkan masalah hukum, sistem hukum dan mengkajinya atau menganalisisnya dengan mempergunakan teori hukum secara runtut yang sesuai dengan kebutuhan dari penelitian ini, yaitu mengenai tinjauan yuridis keterbukaan informasi di perbankan.

\section{B.3. J enis Data}

Data yang digunakan dalam penelitian ini adalah data sekunder. Data sekunder adalah data yang terdiri dari:

Bahan Hukum Primer berupa peraturan perundang - undangan yang terkait dengan keterbukaan informasi di perbankan;

\footnotetext{
5 Soerjono Soekanto, Pengantar Penelitian Hukum, cet. III, (Jakarta: Penerbit Universitas Indonesia (UI -Press), 2007), halaman 3.
}

Bahan Hukum Sekunder berupa doktrin yang dipergunakan dalam menganalisa penelitian ini;

> Bahan Hukum Tersier berupa pernyataan seseorang di website/ media cetak, makalah penelitian dan jurnal.

\section{B.4. Metode Pengumpulan Data}

Bahan hukum dikumpulkan dengan menggunakan sistem kartu (cardsystem)6. Dalam pengumpulan bahan hukum tersebut, kartu - kartu disusun berdasarkan topik, bukan berdasarkan nama pengarang. Bahan - bahan yang terdapat dalam kartu antara lain: permasalahan, argumentasi/ pendapat, mekanisme yang dijalani, konsekuensi dan alternatif solusi permasalahan serta konsep - konsep yang terkait dengan isu hukum tertentu. Hal ini dilakukan agar memudahkan dalam hal penguraian, menganalisa dan membuat kesimpulan dari konsep - konsep yang ada.

\section{B.5. Metode Analisis Data}

Penelitian ini mempergunakan metode analisis data secara deskriptif kualitatif. Bogdan dan Taylor sebagaimana dikutip oleh Moleong memberikan definisi deskriptif kualitatif adalah prosedur penelitian yang menghasilkan data deskriptif berupa kata - kata baik secara tertulis atau lisan

${ }^{6}$ http://www.pps.unud.ac.id/thesis/pdf thesis/unud-321tesissuksma.pdf diakses pada tanggal 27 Februari 2015 yang mengutip Winarno Surakhmad, Pengantar Penelitian IImiah, Dasar Metode \& Teknik, (Bandung: Tarsito, 1972), halaman 257. 
dari orang atau lembaga dan perilaku yang dapat diamati, yang diarahkan pada latar dan individu tersebut secara holistik?.

Bahan hukum yang berupa himpunan peraturan perundang - undangan yang berkaitan dengan keterbukaan informasi di perbankan yang telah dinventarisir dan disusun kemudian dilakukan analisis data. Analisis data dilakukan dalam rangka untuk memecahkan permasalahan yang ada dengan sistematika:

a) Menggambarkan permasalahan (deskripsi);

b) Menjelaskan pokok - pokok permasalahan (eksplanasi);

c) Mengkaji permasalahan dari bahan - bahan hukum yang terkait (evaluasi) dan;

d) Memberikan argumentasi dari hasil evaluasi tersebut;

dari melaksanakan kegiatan tersebut diatas sehingga didapat kesimpulan (sintesa) mengenai persoalan implementasi peraturan perundang undangan yang berkaitan dengan keterbukaan informasi di perbankan.

\section{PEMBAHASAN}

\section{C.1. Penerapan Peraturan Perundang - Undangan Keterbukaan Informasi Publik Di Perbankan.}

Perbankan yang termasuk sebagai badan publik memiliki kewajiban guna melaksanakan segala ketentuan yang terdapat pada Undang Undang Nomor 14 Tahun 2008 Tentang Keterbukaan Informasi Publik. Namun disisi yang lain perbankan juga termasuk industri yang padat modal dan rigid. Pengaturan segala kebijakan operasional perbankan diatur secara mendetail oleh regulator (Otoritas Jasa Keuangan) dikarenakan terintegrasi dengan kebijakan moneter dan fiskal pemerintah.

\section{C.1.1.Pelaksanaan Keterbukaan Informasi Publik Sesuai Dengan Undang - Undang Nomor 14 Tahun 2008 Tentang Keterbukaan Informasi Publik di Badan Publik.}

7https://docs.google.com/document/d/1ZnjG5zB2GzhppEoMc ZFpWXeGDQWKwHU786F6JaYWm01/edit?pli=1 diakses pada tanggal 12 Agustus 2015 yang mengutip Moleong., Lexy, Metode Penelitian Kualitatif, (Bandung: Remaja Rosda, 2002) halaman 3. 


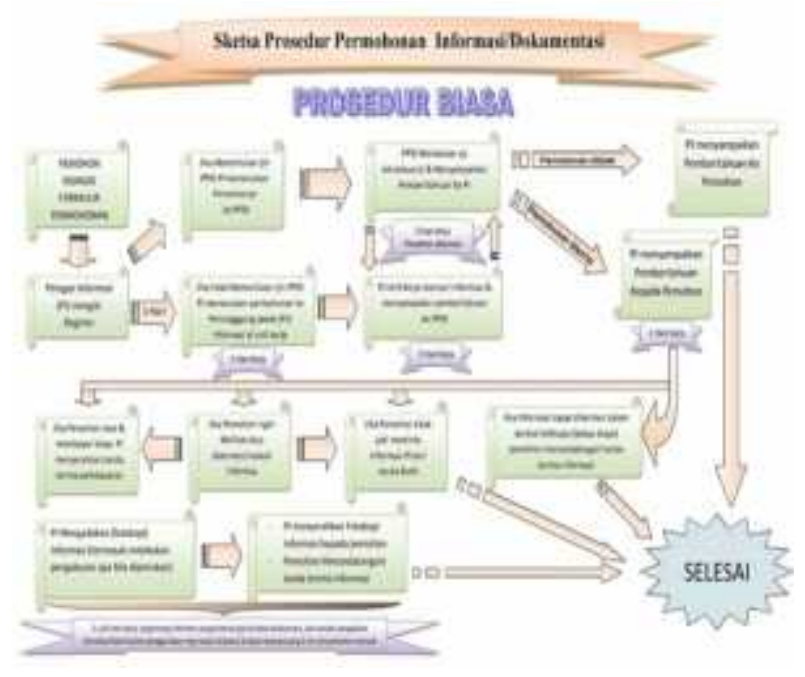

Skema Prosedur Permohonan Informasi/ Dokumen8.

Jenis Informasi Terbuka

\section{Informasi Wajib Yang Disediakan dan} Diumumkan Secara Berkala adalah Terdiri Antara lain:

Informasi tentang profil dan identitas kantor/ unit kerja, sarana serta informasi kegiatan badan publik antara lain LHKPN, CV pejabat, ringkasan Laporan Keuangan, Laporan Akses Informasi Publik, Tata Peraturan Internal Badan Publik, Tata Cara Perolehan dan Pengaduan Penyalahgunaan Wewenang dan sebagainya.

\section{Informasi Publik Yang Wajib Diumumkan} Secara Serta Merta antara lain:

\footnotetext{
${ }^{8}$ http://pn-lubukpakam.go.id/17-2/sop-pengambilan-informasil/ diakses pada tanggal 11 September 2015.
}

Informasi Publik Yang Wajib Diumumkan Secara Serta Merta adalah informasi yang dapat mengancam hajat hidup orang banyak dan ketertiban umum lainnya yang memuat Informasi tentang bencana alam,keadaan bencana non alam, bencana seperti kerusuhan, konflik antar kelompok atau antar komunitas masyarakat dan informasi tentang jenis, persebaran dan daerah yang menjadi sumber penyakit dan sebagainya

III. Informasi Publik Wajib Tersedia Setiap Saat antara lain:

Informasi tentang peraturan, keputusan dan/atau atau kebijakan Badan Publik, Seluruh informasi lengkap yang wajib disediakan dan diumumkan secara berkala, Informasi tentang organisasi, administrasi, kepegawaian, dan keuangan dan sebagaainya.

\section{IV.Tahapan Penyusunan Informasi Publik Yang}

\section{Terbuka}

\section{Identifikasi dan Klasifikasi Informasi Publik}

Identifikasi informasi merupakan tahapan untuk menginventarisasi berbagai macam informasi yang ada dalam penguasaan badan publik. Baik dalam aspek jenis, bentuk, kategori, lokasi penyimpanan, pengecualian dan jangka waktu pengecualian hingga pengelola atau pejabat yang berhak atau menguasai informasi tersebut. 


\section{Pembuatan Daftar Informasi Publik Yang Terbuka}

PPID dapat mengumpulkan kategori informasi untuk menyusun daftar informasi

Dalam hal penetapan dapat dilakukan, informasi yang di kecualikan menjadi terbuka pada saat berakhirnya jangka waktu pengecualian?

\section{Tahapan Penyusunan Informasi Publik yang Dikecualikan}

Informasi yang dikecualikan tidak bersifat permanen kecuali Informasi Publik yang apabila dibuka dapat mengungkapkan isi akta otentik yang bersifat pribadi dan kemauan terakhir ataupun wasiat seseorang dan Informasi Publik yang apabila dibuka dan diberikan kepada Pemohon Informasi Publik dapat mengungkap rahasia pribadi (Pasal 17 butir g dan h Undang Undang Nomor 14 Tahun 2008 Tentang Keterbukaan Informasi Publik). Tidak bersifat permanen artinya informasi tersebut dibatasi jangka waktu tertentu. Sifat tidak permanen juga dapat didasarkan pada keputusan dan ijin persetujuan tertulis dari Komisi informasi setelah sengketa atau mediasi atau pun karena keputusan pimpinan satuan kerja.

${ }^{9}$ https://dodisolihudin.wordpress.com/2013/12/25/penyu sunan-informasi-publik-yang-terbuka-dan-dikecualikan/ diakses pada tanggal 14 September 2015.

\section{Uji Konsekuensi Oleh PPID Dengan} Melibatkan Pejabat Setiap Unsur PPID

Dilakukan dengan melakukan identifikasi relevansi permohonan informasi publik dengan ketersediaan informasi publik oleh Badan Publik beserta konsekuensi yang timbul atas penyebaran informasi publik.

\section{A. Penerapan Keterbukaan Informasi Publik Di Perbankan}

Krisis ekonomi yang terjadi pada tahun 1998 (awal krisis tidak lepas dari tidak berjalannya prudential banking) telah merubah sebagian besar fundamental ketatanegaraan Indonesia. Kemudahan mendirikan bank di kurun waktu 1980an mengakibatkan bermunculan banyaknya bank di Indonesia yang pada tahun 1998 mengalami kebangkrutan.

Sejumlah peraturan perundang - undangan mengalami perubahan yang signifikan pasca krisis ekonomi 1998. Tidak terkecuali pelaksanaan kegiatan usaha perbankan yang mengalami transformasi dari semula mengabaikan ketentuan tata kelola perusahaan yang baik (Good Corporate Governance) dan manajemen risiko berubah $180^{\circ}$ menjadi badan usaha yang taat asas dan aturan.Maka pemerintah (regulator) mencanangkan Arsitektur Perbankan Indonesia.

Kebijakan ini mendorong optimalisasi peran 
fungsi intermediasi bank sekaligus agen pembangunan bangsa dan negara. Karena sektor jasa keuangan merupakan sektor strategis dalam upaya membangun perekonomian suatu negara tidak terkecuali Indonesia.

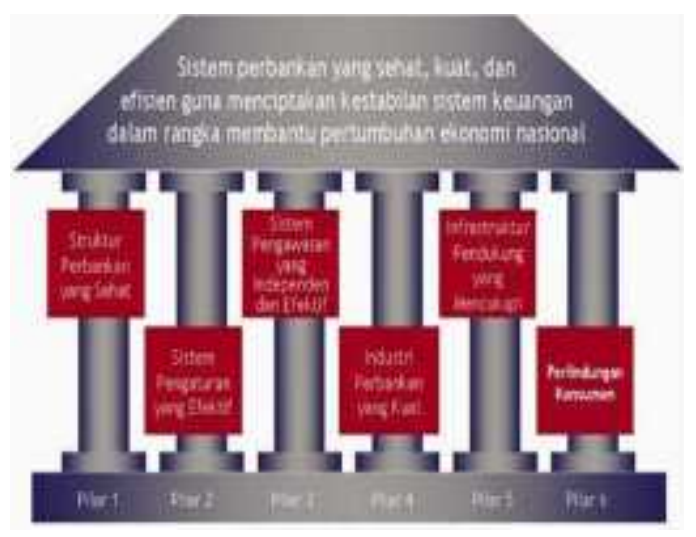

\section{Enam Pilar Arsitektur Perbankan Indonesia}

Guna mempermudah pencapaian visi Arsitektur Perbankan Indonesia maka ditetapkan beberapa sasaran yang ingin dicapai, yaitu:

1. Menciptakan struktur perbankan yang sehat yang mampu memenuhi kebutuhan masyarakat dan mendorong pembangunan ekonomi nasional yang berkesinambungan;

2. Menciptakan pengaturan dan pengawasan bank yang efektif dan mengacu pada standar internasional;

3. Menciptakan struktur perbankan yang kuat dan memiliki daya saing yang tinggi serta memiliki ketahanan dalam menghadapi risiko;
4. Menciptakan Tata Kelola Perusahaan Yang Baik (Good Corporate Governance) dalam rangka memperkuat kondisi internal perbankan nasional;

5. Mewujudkan infrastruktur yang lengkap untuk mendukung terciptanya struktru perbankan yang sehat;

Wujud dari Arsitektur Perbankan Indonesia adalah Tata Kelola Perusahaan Yang Baik (Good Corporate Governance) yang dijalankan perbankan dengan membuka akses informasi publik dengan menggunakan berbagai macam media antara lain website, laporan tahunan, laporan kinerja operasional dan sebagainya. Unit kerja yang menjalankan komunikasi internal maupun komunikasi eksternal (shareholder) dan/ atau komunikasi eksternal (pemerintah/ masyarakat) (biasanya disebut sebagai humas/ hubungan masyarakat) ini diwajibkan mengimplementasikan manajemen risiko dalam kegiatan operasional. Mewujudkan pemberdayaan dan perlindungan konsumen jasa perbankan ${ }^{10}$.

\footnotetext{
${ }^{10}$ http://ayusaputri9.blogspot.co.id/2014/01/bab-3pengertian-arsitektur-perbankan.html diakses pada tanggal 01 November 2015.
} 
B. Jenis - Jenis Informasi Yang Terdapat

\section{Benturan Kepentingan Sebagaimana}

Diatur Dalam Peraturan Perundang -

Undangan Yang Terkait Keterbukaan Informasi Publik.

1. Informasi Terkait Laporan Keuangan Bank.

Benturan kepentingan:

Pasal 9 Undang - Undang Nomor 14 Tahun 2008 Tentang Keterbukaan Informasi Publik;

> Pasal 10 Peraturan Otoritas Jasa Keuangan No. 6/ POJK. 03/ 2015 Tentang Transparansi dan Publikasi Laporan Bank. Benturan kepentingan yang terjadi adalah antara keberlanjutan usaha bank dengan kepentingan masyarakat.;

2. Laporan Hasil Pemeriksaan Bank. Benturan kepentingan:

Pasal 9 Undang - Undang Nomor 14 Tahun 2008 Tentang Keterbukaan Informasi Publik;

Pasal 12 Peraturan Bank Indonesia No: 8/ 4/ PBI/ 2006 Tentang Pelaksanaan Good Corporate Governance Bagi Bank Umum;

Benturan kepentingan yang terjadi adalah antara keberlanjutan usaha bank dengan kepentingan masyarakat serta pemerintah.

3. Dokumen pendukung seperti naskah akademis, kajian atau pertimbangan yang mendasari terbitnya peraturan, keputusan atau kebijakan tersebut.

Benturan kepentingan:

Pasal 9 Undang - Undang Nomor 14 Tahun 2008 Tentang Keterbukaan Informasi Publik;

Pasal 25 Peraturan Bank Indonesia No: 8/ 4/ PBI/ 2006 Tentang Pelaksanaan Good Corporate Governance Bagi Bank Umum;

Pasal 12 Peraturan Otoritas Jasa Keuangan No. 6/ POJK.03/ 2015 Tentang Transparansi dan Publikasi Laporan Bank;

Benturan kepentingan yang terjadi adalah antara keberlanjutan usaha bank dengan kepentingan masyarakat dan competitor.

4. Masukan - masukan dari berbagai pihak atas peraturan, keputusan atau kebijakan tersebut.

Benturan kepentingan:

Pasal 9 Undang - Undang Nomor 14 Tahun 2008 Tentang Keterbukaan Informasi Publik;

Pasal 25 Peraturan Bank Indonesia No: 8/ 4/ PBI/ 2006 Tentang Pelaksanaan Good Corporate Governance Bagi Bank Umum; Benturan kepentingan yang terjadi adalah antara keberlanjutan usaha bank dengan kepentingan masyarakat. 
5. Risalah rapat dari proses pembentukan peraturan, keputusan atau kebijakan tersebut.

Benturan kepentingan:

Pasal 9 Undang - Undang Nomor 14 Tahun 2008 Tentang Keterbukaan Informasi Publik;

Pasal 25 Peraturan Bank Indonesia No: 8/ 4/ PBI/ 2006 Tentang Pelaksanaan Good Corporate Governance Bagi Bank Umum;

Pasal 12 Peraturan Otoritas Jasa Keuangan No. 6/ POJK.03/ 2015 Tentang Transparansi dan Publikasi Laporan Bank;

Benturan kepentingan yang terjadi adalah antara keberlanjutan usaha bank dengan kepentingan masyarakat dan antar bank/ kompetitor.

\section{Penerapan Manajemen Risiko Dalam Penerapan Keterbukaan Informasi Publik Di Perbankan}

Penerapan Manajemen Risiko (Risk Management) dalam penerapan keterbukaan informasi di perbankan dilaksanakan dengan urutan identifikasi kegiatan, perencanaan, pelaksanaan, monitoring dan evaluasi. Pembuatan sistematika penerapan ini guna memudahkan pengendalian risiko yang berpotensi terjadi selama kegiatan operasional bank terkait pelaksanaan keterbukaan informasi bank.
Kegiatan yang dijadikan contoh adalah kegiatan penyusunan Laporan Tahunan Bank (Annual Report) mulai dari tahap identifikasi kegiatan sampai evaluasi kegiatan.

1. Identifikasi Kegiatan

Penetapan batas batasan risiko yang ditetapkan oleh bank (Risk Tolerance) tertuang dalam Rencana Bisnis Bank, pengaturan secara ketat sesuai dengan 8 (delapan) jenis risiko dan batasan risiko yang ditetapkan oleh bank (Risk Tolerance). dilakukan oleh bank dikarenakan hal ini dapat mempengaruhi komposisi neraca bank.

2. Perencanaan Kegiatan

Pada aspek perencanaan kegiatan, humas bank menyusun rencana kegiatan memperhatikan sejumlah instrumen yang diidentifikasi dari sejumlah potensi risiko yang muncul dari tahap identifikasi risiko yang disusun bersama dengan Risk Management Unit. Mekanisme perencanaan kegiatan yang telah disusun telah selesai dilakukan maka kewajiban menyerahkan rencana kegiatan penyusunan Laporan Tahunan kepada atasan salah satu indikator penilaian kinerja (Key Performance Indicator). Pelaksanaan Kegiatan Humas bank berkewajiban melaksanakan kegiatan penyusunan Laporan Tahunan secara mandiri dan/ atau bekerjasama dengan 
mitra kerja/ vendor yang berpengalaman Risiko Hukum : 0,50

sesuai dengan timeline serta kerangka acuan Risiko Kepatuhan : 0,50

kerja yang dibuat bank. Pelaksanaan kegiatan Risiko Pasar $\quad: 0,50$

penyusunan Laporan Tahunan selain Risiko Likuiditas : 0,50

dilaksanakan oleh humas bank juga didukung Risiko Operasional : 0,50

oleh fungsi lain dalam memasok kebutuhan Risiko Kredit : 0,50

data/ konten didalamnya. Risiko Reputasi : 0,50

Wujud dari penerapan Prinsip Manajemen Risiko Ilustrasi Sederhana Verifikasi Data Penyusunan

dalam Laporan Tahunan Korporat/ Laporan Laporan Tahunan Di Perbankan

Publikasi Tahunan/ Laporan Tahunan adalah Pendekatan pengukuran manajemen risiko penghitungan potensi risiko dalam penyajian konten dipergunakan perbankan wajib disesuaikan dengan publikasi. Bahwa pengelolaan manajemen risiko tujuan, kebijakan usaha, ukuran dan kompleksitas dikenal dengan 2 (dua) pembagian yaitu Inherent usaha serta kemampuan Bank sebagaimana diatur Risk dan Kualitas Penerapan Manajemen Risiko (KPMR). Dan setiap bagian tersebut diberikan skor dan/ atau dianalisis dari 8 jenis risiko yang ada di perbankan antara lain: risiko strategis, risiko hukum, risiko kepatuhan, risiko pasar, risiko likuiditas, risiko operasional, risiko kredit, risiko reputasi.

Data/ Kegiatan Potensi Risiko Scoring Inherent Risk Kualitas Penerapan Manajemen Risiko (KPMR) oleh Pasal 3 PBI No: 5/ 8/ PBI/ 2003 tanggal 19 Mei 2003 Tentang Penerapan Manajemen Risiko Bagi Bank Umum, sebagaimana telah diubah dengan PBI No: 11/ 25/ PBI/ 2009 tanggal 1 Juli 2009 Tentang Perubahan Atas PBI No: 5/ 8/ PBI/ 2003 Penerapan Manajemen Risiko Bagi Bank Umum.

penyusunan Laporan Tahunan Bank.

Tabel Tingkat Risiko Inherent Dan Kualitas Penerapan Manajemen Risiko

Data Core Plan 2015 - 2017

Risiko Reputasi.Data Core Plan 2015 - 2017 dengan koefiesien 1 layak dimuat.

NB : Bobot Risiko

Koefiesien

Risiko Strategis $\quad: 0,50$ 
Likelihood Dampak

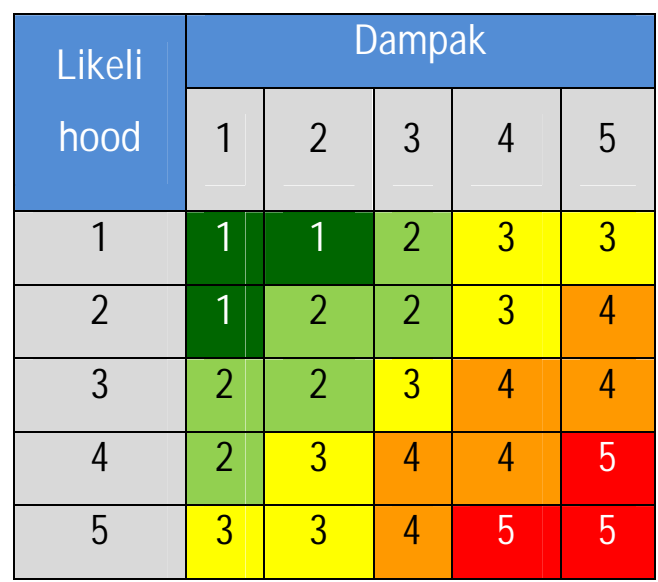

Keterangan :

1 : Low

\section{2: Low to Moderate}

3 : Moderate

4 : Moderate to High

5 : High Risk

\section{Proses Mitigasi Risiko Penyusunan Laporan}

Tahunan

Proses mitigasi diberikan untuk masing - masing risk issue diawali dengan menentukan risk response yang diberikan terhadap masing - masing potensi kejadian risiko (risk event) atas konten yang akan disusun dalam penyusunan Laporan Tahunan yang merupakan tindakan korporasi yang dilaksanakan oleh Bank antara lain
a. Menerima risiko;
b. Menghindari risiko;
c. Mengurangi risiko; dan/atau
d. Membagi risiko.

Proses Penetapan Tingkat Risiko Akhir Penyusunan Laporan Tahunan.

Proses Penetapan Tingkat Risiko Akhir ditetapkan sebagai berikut:

$>\quad$ Untuk potensi Risk Event yang direspon dengan 'menerima risiko', maka tingkat risiko akhir sama dengan tingkat risiko awal (tidak ada perubahan);

Untuk potensi Risk Event yang direspon dengan "membagi risiko", dan "mengurangi risiko", maka tingkat risiko akhir ditetapkan turun 1 (satu) peringkat dari tingkat risiko awal;

> Untuk potensi risk event yang direspon dengan "menghindari risiko", maka tingkat risiko akhir ditetapkan sama dengan tingkat risiko "LOW".

Setelah dilakukan proses mitigasi risiko dan penetapan tingkat risiko akhir data yang dipergunakan dalam penyusunan Laporan Tahunan maka selanjutnya adalah mendesain tampilan fisik dengan mempergunakan aplikasi desain grafis. Setelah desain Laporan Tahunan sudah jadi dan telah mendapatkan persetujuan dari Manajemen Bank (dalam hal ini Direktur Utama Bank). Maka Laporan Tahunan Bank tersebut disampaikan kepada Otoritas Jasa Keuangan (OJK) dan/ atau instansi lainnya serta website bank. 
Guna mengimplementasikan penerapan Prinsip

Tata Kelola Perusahaan (Good Corporate

Governance) dan prinsip manajemen risiko maka lembaga perbankan diwajibkan melakukan penyampaian Laporan Tahunan di website bank dan/ atau diserahkan kepada Otoritas Jasa Keuangan (OJK) sebagaimana diatur dalam Pasal 31 Ayat 1 Peraturan Otoritas Jasa Keuangan No. 6/ POJK. 03/ 2015 Tentang Transparansi dan Publikasi Laporan Bank. Pengunggahan ke website bank selain memudahkan akses publik juga seiring dengan penyediaan akses informasi publik bagi publik baik yang berkala, wajib tersedia, serta merta.

Website bank dikelola dengan mempergunakan sumber daya sendiri dan/ atau mempergunakan mitra kerja/ vendor. Sedangkan konten yang ada dikelola oleh humas bank termasuk pengkinian data - data yang wajib tersedia antara lain: sejarah dan perkembangan bank dari masa ke masa, informasi struktur pemilik dan manajemen bank, informasi produk dan layanan bank, informasi suku bunga dana dan/ atau kredit, mekanisme pengajuan kredit dan/ atau pembukaan rekening, informasi jaringan operasional bank, pemberitaan kegiatan bank, laporan keuangan baik bulanan, triwulanan dan tahunan, laporan GCG Self Assesment termasuk Laporan Tahunan Bank.

\section{PENUTUP}

\section{D.1. SIMPULAN}

Penerapan peraturan perundang - undangan Keterbukaan Informasi Publik telah dilakukan oleh pelaku industri perbankan sesuai dengan ketentuan yang berlaku. Namun demikian berdasarkan hasil penelitian masih terdapat beberapa kekurangan dalam penerapan perundang - undangan Keterbukaan Informasi Publik yaitu:

1) Pelaksanaan kegiatan operasional bank masih bersifat parsial tidak terintegrasi dari hulu sampai dengan hilir serta benturan kepentingan sebagaimana diatur dalam peraturan perundang - undangan yang terkait keterbukaan informasi publik secara yuridis dapat diminimalisir dengan penerapan doktrin hukum antara lain: Lex Superior Derogat Legi Inferiori. Lex Specialis Derogat Legi Generalis dan Asas Lex Posterior Derogat Legi Priori. Namun dari hasil penelitian ditemukan fakta bahwa diperlukan sebuah peraturan pelaksanaan keterbukaan informasi di perbankan yang lebih rinci mengatur jenis informasi yang dapat diakses oleh publik baik informasi wajib disediakan dan diumumkan, informasi serta merta, informasi yang dikecualikan.

2) Penerapan manajemen risiko dalam penerapan keterbukaan informasi publik di perbankan 
mutlak dilakukan khususnya saat pelaksanaan pemenuhan informasi publik baik yang berupa informasi wajib disediakan dan diumumkan, informasi serta merta, informasi yang Dikecualikan mengingat tanggung jawab bank agen pembangunan (Agent of Change) dan fungsi intermediasi (Financial Intermediacy) serta kewajiban menjaga kerahasiaan nasabah (Bank Secrecy).

3) Keterbukaan Informasi Publik Yang Ideal di Perbankan dimaknai sebagai keselarasan antara kepentingan publik akan akses informasi dengan perlindungan usaha bank. Salah satu upaya yang strategis dalam menjaga keselarasan tersebut adalah penerbitan peraturan pelaksana dari Undang - Undang Nomor 14 Tahun 2008 Tentang Keterbukaan Informasi Publik khusus perbankan oleh Otoritas Jasa Keuangan yang berbasiskan pada Penerapan Tata Kelola Pemerintahan Yang Baik (Good Corporate Governance) dan Penerapan Manajemen Risiko (Risk Management) pada setiap proses bisnis pelaksanaan keterbukaan informasi publik.

\section{D.2. SARAN}

Dari hasil penelitian dan pembahasan sebagaimana diuraikan diatas maka penulis memberikan saran terkait Keterbukaan Informasi Publik di Perbankan sebagai berikut :
1) Regulator dalam hal ini Otoritas Jasa Keuangan perlu menyusun peraturan pelaksanaan Keterbukaan Informasi Di Perbankan guna menghindari munculnya risiko hukum dan risiko kepatuhan bank serta perlunya penyempurnaan Undang - Undang Nomor 14 Tahun 2008 Tentang Keterbukaan Informasi Publik (KIP) khususnya terkait pengecualian penyampaian informasi publik di perbankan yang terkait Laporan Pemeriksaan Atas Bank bagi bank BUMN/ BUMD.

2) Kaji ulang ketentuan peraturan perundang undangan keterbukaan informasi publik di perbankan yang saling berbenturan satu sama lain agar sinergis dan terintegrasi.

3) Penguatan fungsi unit humas dan unit manajemen risiko dalam bank sebagai unit yang mengelola uji konsekuensi atas permintaan informasi publik yang dikuatkan dalam sebuah ketentuan yang diterbitkan oleh Otoritas Jasa Keuangan baik berupa Peraturan Otoritas Jasa Keuangan dan Surat Edaran Otoritas Jasa Keuangan.

\section{DAFTAR PUSTAKA}

Abdurrahman, A, 1993, Ensiklopedia Ekonomi Keuangan Perdagangan, Jakarta: Pradnya Paramita. 
Jurnal Law Reform

Volume 12, Nomor 2, Tahun 2016

Arifin, Zainul, 2005, Dasar-Dasar Manajemen Bank Syariah, Jakarta: Pustaka Alvabet.

Asshidiqie, Jimmy, 2006, Perkembangan dan Konsolidasi Lembaga Negara Pasca Reformasi, Jakarta: Sekretariat Jenderal dan Kepaniteraan Mahkamah Konstitusi RI. , 2006, Pengantar IImu Hukum Tata Negara Jilid I, Jakarta: Sekretariat Jenderal dan Kepaniteraan Mahkamah Konstitusi RI.

., 2010, Konstitusi Ekonomi, Jakarta: Penerbit Buku Kompas.

Aziz Hakim, Muhammad, 2012, Politik Hukum Sistem Pemilihan Umum di Indonesia Pada Era Reformasi, Jakarta: Universitas Indonesia.

Bahasa, Pusat, 2008, Kamus Besar Bahasa Indonesia Edisi Keempat, Jakarta: PT Gramedia Pustaka Utama.

Bungin, Burhan, 2003, Analisis Data Penelitian, Pemahaman Filosofis dan Metodologis Ke Arah Penguasaaan Model Aplikasi, Jakarta: Rajagrafindo Persada.

Daniri, Mas Achmad, 2005, Good Corporate Governance Konsep dan Penerapannya
Program Studi Magister Ilmu Hukum Fakultas Hukum Universitas Diponegoro

Dalam Konteks Indonesia Raya, Jakarta: Ray Indonesia.

Farida Indrati Soeprapto, 2010, IImu PerundangUndangan : Jenis, Fungsi, dan Materi Muatan, Yogyakarta: Kanisius.

HR, Ridwan, 2013, Hukum Administrasi Negara, Yogyakarta: UII Press Yogyakarta.

Ibrahim, Johny, 2006, Teori dan Metodologi Penelitian Hukum Normatif, Malang: Bayu Media.

Indonesian Center for Environmental Law (ICEL), Komisi Informasi Pusat Republik Indonesia, 2009, Anotasi Undang-Undang Nomor 14 Tahun 2008 Tentang Keterbukaan Informasi Publik (Edisi Pertama), Jakarta: Yaysan TIFA.

Mahfud MD, Moh, 2009, Politik Hukum di Indonesia, Jakarta: Rajagrafindo Persada.

Mertokusumo, Sudikno, 2009, Penemuan Hukum Sebuah Pengantar, Yogyakarta: Penerbit Liberty.

Veithzal Rivai dkk, 2007, Bank and Financial Institution, Jakarta: Rajagrafindo Persada.

Sembiring, Sentosa, 2012, Hukum Perbankan, Bandung: Mandar Maju. 
Jurnal Law Reform

Volume 12, Nomor 2, Tahun 2016

Siahaan, Lintong Oloan, 2006, Wewenang PTUN Menunda Berlakunya Keputusan Pemerintah, Jakarta: Perum Percetakn Negara RI.

Soekanto, Soerjono, 2007, Pengantar Penelitian Hukum, Cet.III, Jakarta: Penerbit Universitas Indonesia (UI-Press).
Program Studi Magister Ilmu Hukum Fakultas Hukum Universitas Diponegoro 